\title{
RICHARD WAGAMESE'S INDIAN HORSE: STOLEN MEMORIES AND RECOVERED HISTORIES
}

\author{
MEMORIA ROBADA E HISTORIAS RECOBRADAS EN \\ INDIAN HORSE DE RICHARD WAGAMESE
}

Franck Miroux

Université Toulouse Jean-Jaurès

\section{ABSTRACT}

This paper purports to explore the narrative devices which enable the Anishinaabe Canadian author Richard Wagamese to compel the reader of his novel Indian Horse (2012) to experience the same violence as that faced by the young protagonist when the repressed memory of the terrible abuse suffered at an Indian residential school resurfaces decades after, disrupting the apparently linear course of the story. This study also seeks to show that Wagamese offers a major contribution to the rewriting of the history of residential schools in Canada by reclaiming Aboriginal narrative forms as a means to recover stolen memories, and thus to reconstruct both the fragmented (his)story and the shattered self.

Keywords: Wagamese (Richard), residential schools, memory, history (rewriting), Aboriginal literatures (Canada). 


\section{RESUMEN}

Este artículo pone de manifiesto las estrategias narrativas mediante las cuales el autor anishinaabe canadiense Richard Wagamese somete al lector de su novela Indian Horse (2012) a la misma violencia sufrida por el joven héroe cuando la repentina resurgencia del recuerdo traumático reprimido acaba rompiendo la linealidad aparente de su historia. Asimismo, este estudio pretende demostrar que la reapropiación de la memoria robada, y por la tanto la posibilidad de reconstruirse tras el traumatismo vivido, pasan por una reapropiación de las formas aborígenes del relato gracias a las que Wagamese contribuye de manera significativa a la reescritura de la historia de las escuelas residenciales autóctonas de Canadá.

Palabras clave: Wagamese (Richard), escuelas residenciales, memoria, historia (reescritura), literaturas autóctonas (Canadá)

Fecha de recepción 28 de junio de 2019.

Fecha de aceptación: 5 de agosto de 2019.

Cómo citar: Miroux, Franck (2019), «Richard Wagamese’s Indian Horse: Stolen Memories and Recovered Histories», en Actio Nova: Revista de Teoría de la Literatura y Literatura Comparada, 3: 194-230.

DOI: https://doi.org/10.15366/actionova2019.3.009 
Here at the Kiowa Boarding School [...] I am taught not to remember but to dismember myself. N. S. Momaday ${ }^{1}$

At a conference he gave at the University of British Columbia in 2013, Anishinaabe Canadian writer Richard Wagamese said that his novel Indian Horse was «really hard to digest because of its harrowing, and brutal, and honest truth about a chapter in our history and an institution that was the spearhead of that chapter and left a very very deep and long-lasting psychic bruise on our entire consciousness» (Wagamese, 2013). Indian Horse is a partly autobiographical novel which opens on the initial dissolution of the memorial, emotional and cultural ties which once bound a small Aboriginal ${ }^{2}$ community together. The only way for Saul Indian Horse, the young protagonist, to cope with the utter loss of landmarks and references is first to build himself a sheltering space to avoid disintegration, and then to piece together a narrative from the fragmented memories of the years spent at St. Jerome's Indian residential school. This paper therefore purports to assess the extent of the loss incurred by the young Indian boy before exploring how ice hockey serves both for Saul and for Wagamese as an expedient to fill the void resulting from the alienating and dehumanising experience. As we shall see, once the limits of this survival strategy are revealed, a space for creation and expression is cleared up as repressed memories hindering the development of the protagonist and of the narrative alike suddenly resurface. Ultimately, this study will endeavour to focus on how storytelling becomes a means for the young hero and for the novelist to reclaim territories from which they were initially evicted, and, in so doing, to provide a space for reconstruction both at personal and at community levels.

\section{LOSS AND DISPLACEMENT: SURVIVING THE WASTELAND}

The opening lines of the novel leave no doubt as to the tenor of the unfolding narrative as a story of loss and recovery. A homeless young Anishinaabe alcoholic has enrolled in a rehabilitation programme and undertakes to write the story of his wanderings

\footnotetext{
1 See Momaday, 2007: 24.

2 The words «Native», «Aboriginal», «Indian» and «First Nations» are used alternately in this paper to refer to the indigenous communities of Canada and the United States of America.
} 
as part of his therapy $\left(I H: 2-3^{3}\right)$. Telling and recovering immediately appear as interconnected processes and, similarly, the imbricated narratives function as a reminder that Saul's story and Wagamese's biography constantly intertwine in the novel.

As a matter of fact, it is hard to dissociate the state of utter deprivation in which Saul is left after being removed from his Native community from the author's own experience of abandonment when his drunken parents vanished and he was placed into foster care in various white families. After all, Wagamese experienced solitude, alienation and confinement just like his young hero does when he is sent to St. Jerome's (Wagamese, 2008: $3)$.

The novelist, who knows full well what it means to be uprooted and relocated, adopts a clear stance on the destructive effects of colonisation by setting his narrative in an environment already corrupted by the invasion of foreign elements. Although the novel does mention a prelapsarian world, such a space is not to be found in the world in which Saul grew up before being forced to move to St. Jerome's. It has to be traced back to the founding myth encapsulating the history of Saul's clan-in a dreamtime of sorts when the community still acted as a whole and when the traditional social structures had not yet been fragmented by the intrusion of white norms and standards. It is interesting, however, to stress that even then, traces of invasion could already be found in the very story accounting for the origins of Saul's name. Indeed, the name earned by his great-grandfather, Indian Horse, is directly linked to the introduction of a foreign element in the tribe- a draft horse left behind by white settlers-announcing irreversible changes to which the tribe will have to adapt to avoid destruction:

I walked with it upon the plains and the horse offered me his teachings. «A great change will come. It will come with the speed of lightning and it will scorch all our lives. [...] But we must learn to ride each one of these horses of change. It is what the future asks of us and our survival depends on it. (IH: 4-7)

This early intrusion of the so-called dominant culture into both Wagamese's narration and Saul's tribal narrative foreshadows further dispossessions and alterations that will have a tremendous impact on Native communities. As it happens, the world in which

\footnotetext{
${ }^{3}$ All the references reading $(I H:+$ page number) refer to Wagamese's Indian Horse.
} 
Saul and Wagamese were born had not only already been altered by the intrusion of alien elements, but it had also been corrupted and shattered by the so-called emancipation policy implemented by the Canadian government ${ }^{4}$. As early as in Chapter 4, the novel focuses on an absence rather than a presence within this small Aboriginal community-that of the children «spirited away by the government men» (IH: 14). This absence had already been accounted for in the previous chapter, where Saul and his grandmother Naomi alternately recount the events that led to the abduction of Saul's elder siblings, Rachel and Benjamin. Both children try to escape in the bush and are hunted like wild animals by the Indian agents who ship them to residential school (IH: 9-10).

These recollections of the past dispossessions inflicted on the community do more than just remind the reader of the extent of the violence suffered by First Nations people at the hands of federal agents; they ground the narration of Saul's story and of the history of Wagamese's people on despoilment and deprivation.

Deprived of its younger generation, and consequently of future prospects and hopes, the small group composed of Saul, his grandmother Naomi, his brother Benjamin, his parents and his aunt can no longer hope for the restoration of a precolonial order since all of them, except Naomi and Saul, have already been corrupted by over exposition to the white world. Images of a tribal order irretrievably altered and of alienated Indian characters struggling to reconnect with the tribe after being immersed in the white man's world are a recurrent feature of Native literatures, in novels such as House Made of Dawn ${ }^{5}$ or The Death of Jim Loney ${ }^{6}$ for instance. Indian Horse is no exception as two generations of displaced and estranged characters fail to reconnect with their heritage and traditions. Benjamin is probably the most striking example of the destructive effects of the Indian education system in terms of mental and physical integrity. When he runs away from the residential school and manages to find his way back to his family's camp, the others are faced with a degraded version of the young boy they used to know:

\footnotetext{
4 «Emancipation» was the word used for «assimilation» in many official documents drafted by the Federal government of Canada between the year 1876, when the infamous Indian Act was passed, and 1969, when a campaign against Pierre Trudeau's white paper led by First Nations activists forced the government to backpedal on its emancipation agenda.

5 (Momaday 1968).

${ }^{6}$ (Welch 1975).
} 
His hair was cropped close to his skin and his ill-fitting clothes were made even looser by the weight he'd lost on his journey. «For a moment, no one knew who he was. [...] He was different. Not only in size. There was a wariness in his eyes and a hardness to the set of his chin. [...] It was odd to see the expressions of a grown man on a boy's face. Then, he coughed.» (IH: 16)

Benjamin has become a stranger to his clan and soon finds himself excluded from the group since contact with the dominant and repressive culture has left him both undesirable and unfit. His coughing, one of the symptoms of tuberculosis contracted in the cold dormitory of the school, is undoubtedly the physical sign of the destructive process initiated there. Additionally, it disqualifies him as an active participant in the rice picking ceremony orchestrated by Naomi to help her grandchildren maintain a connexion with their Anishinaabe spiritual heritage and heal their bodies and minds. Taking part in the ceremony only makes his coughing worse. This is most certainly a portent of his impending demise, and, as the spumes of blood he expectorates stain the clean white rice, we are once more reminded of how degraded the small indigenous community already is (IH: 28-29).

In addition to Benjamin's lethal ailment, Saul's parents, who were both forced to attend residential school in their childhood, are also a corrupted version of their former selves. His mother, for instance, resembles a zombie devoid of all substance and will. When she is drunk, she dances around the fire casting horrific and skeletal shadows on the skin of the tent (IH: 10). In her empty eyes, the residential schools hover like a ghostly presence as she endlessly tries to drown her misery: «There was a spectre in our camp. We could see the shadows of this dark being in the lines of our mother's face. [...] It was the school that had turned my mother so far inward she sometimes ceased to exist in the outside world. » (IH: 8$9)$.

As Rigal-Cellard reminds us in her reference book on Indian literatures Le mythe et la plume (2004), the fragmentation and dismembering of Native communities often reconfigured family structure by giving grandparents a key role in maintaining the connexion between the children and their cultural background (Rigal-Cellard, 2004: 76). This is precisely what happens in the novel where Naomi is the only adult in the group able to pass on the myths and the stories of the clan to her grandson. Being the only member of the family not to have been subjected to the process of acculturation at work in the Indian residential school 
system, she is still an apt storyteller. The sacred stories she tells Saul act as many talismans which protect him from the surrounding dangers and violence: «Naomi told me stories, kept me away from the adults when they were in the grips of the drink.» (IH: 14).

Yet, for all the efforts Naomi makes to hold the group together, the scars left by the boarding schools on Saul's parents are so deep that disintegration and dismembering cannot be avoided. As they vanish in the distance on the lake, carrying away Benjamin's dead body and leaving Saul and Naomi to fend for themselves, the divergent lines in the wake of their canoe further epitomize the final dissolution of the group's social and cultural fabric: «Even now when I think back to that day, I can see the shimmer of the wake they left behind them, the vee of it and the divergent lines that lapped at the shoreline. [...] I can see the canoe that held my brother's body as it passed the rock cairn and slid out of my view forever.» (IH: 33).

What Wagamese insists on here, is the detribalisation and the alienation resulting from the estrangement of Indian children from their families and their tribal environment, a pattern which, as Rigal-Cellard explains, constitutes one of the topoi of Indian literatures (Rigal-Cellard, 2004: 76-77). The severance of the ties that bound Saul to his tribal history is made all the more complete when Naomi dies from exposure while trying to save him from the harshness of an upcoming winter snowstorm. The parallel between Saul's story and Wagamese's own experience is so obvious again that the narrative can be read as the reenactment of the process through which the novelist himself became alienated from his own culture after he was sent to live in white foster families in the $1960 \mathrm{~s}^{7}$. Although Wagamese did not attend residential school, the account he gives of his childhood in the various foster homes where he stayed, and in the many provincial schools he went to, reveals the same feeling of terror, marginalisation and utter solitude as that experienced by Saul at St. Jerome's where he is sent after being found curled up against his grandmother's frozen body (IH: 4142).

At St. Jerome's, the young boy is divested of what is left of his Anishinaabe heritage. Similarly, the text is stripped of any elaborate stylistic devices and devoid of complex structures. The wilful oversimplification of the grammar and the syntax has been identified

\footnotetext{
${ }^{7}$ In Canada, this practice is referred to as the Sixties Scoop. It consisted mostly in removing Indian children from their families to place them into foster care in white families where they attended provincial schools in the hope of facilitating their assimilation.
} 
as one of the means used by Indian writers to mirror the inability of their alienated characters to organise their traumatic memories into a coherent narrative (Rigal-Cellard, 2004: 89). Indian Horse offers a prime example of this strategy at work. Indeed, the journalistic style used by Wagamese to recount the years spent by Saul in the catholic institution appropriately mirrors the boy's distress and inner confusion. In many respects, it is a metonymic reminder of the trauma he endures after being pulled away from Naomi's body and «cast adrift on a strange new river» $(I H: 42)^{8}$. This is particularly striking in this passage where Saul remembers his arrival at St. Jerome's. The shortness and the deliberate simplicity of the sentences, the slack syntax and the factual tone reproduce the fragmented memories left by the highly distressing experience of abduction and relocation:

We'd driven two days to get there. Two nuns and three of us kids crammed into the back seat of a battered old Chev. A little girl who cried most of the way, and another boy. We spent the trip without talking, taking turns at the windows watching the land flow by. It seemed boundless. Every curve in that road, every crest of a hill, even the cut of the trees against the sky held me spellbound. I barely slept. (IH: 43)

At St. Jerome's, Saul's life becomes a wasteland of sorts, as sterile as the barren landscape surrounding the buildings (IH: 43) and as fruitless as the education provided there. As a matter of fact, the most senior nun, Sister Ignacia, makes it very plain upon welcoming the new boarders that education at St. Jerome's is merely a matter of disempowerment and dispossession: «At St. Jerome's we work to remove the Indian from our children so that the blessings of the Lord may be evidenced upon them» (IH: 46-47).

Saul's recollections of the years spent there show how true the nun's warning proved over time. In the long chilly corridors of the school, the pungent smell of disinfectant foreshadows the ordeal which the children have to go through upon their arrival when a pair of nuns force them into a bathtub and scrub their bodies frantically as if to erase all traces of Indianness: «They rubbed us nearly raw. It felt they were trying to remove more than grime or odour. It felt as though they were trying to remove our skin» (IH: 44).

Similarly, the «renaming ceremony», which is a recurrent feature in residential

\footnotetext{
${ }^{8}$ It must also be reminded that before writing works of fiction Wagamese worked as a journalist for a Regina
} indigenous newspaper called The New Breed. 
school narratives, aims at obliterating the child's former life and references. Deprived from their sense of self and of belonging, the young boarders who dare challenge the authority of the priests and nuns to erase their identity face terrible punishments. Such is the case with poor Lonnie Rabbit when he tries to resist Sister Ignacia's decision to rename him Aaron:

The Sister smiled. It was chilling because there was no laughter in her eyes. They were a cold, pale blue, like the eyes of a husky, and when she reached behind her and brought a leather paddle into view she had a terrible calm about her. The paddle was blunt and wide and drilled with holes across its face. She cradled it in both palms, and with a blur of motion she twisted Lonnie around by the collar and pushed him to his knees. He screamed as the paddle struck his back. The nun yanked him to his feet as though he were a rag toy and struck him repeatedly behind the knees and on the back of the thighs. It sounded like she was beating a hide. (IH: 46)

In this passage, Wagamese clearly insists on the state of extreme humiliation and deprivation in which the children are left. In the end, Lonnie loses more than just his identity; he loses his humanity and is treated as if he were a carpet. Unable to react, the young Indians are dealt with as mere objects. They become the passive spectators of the horrors they are forced to witness: «That was perhaps the biggest crime: make us complicit through our mute and helpless witness» ( $I H: 80)$. This passiveness is also reflected in the grammatical shift from the «I» pronoun to «they» at first $(I H: 42-43)$, and then in the abundance of passive forms and causatives depriving the young Indians of their agency, as is the case in this extract in which the young pupils have also ceased to be human: «We were like stock. That's how we were treated. Fed, watered, made to bear our daily burden and secured at night» (IH: 80).

In the end, they are even denied their status as animals. The school, whose nickname- «St. Germ's»—evokes the toxic effect it has on the young Indian wards, becomes a vortex of sorts sucking up the substance within the child and leaving little eviscerated bodies—empty shells devoid of all light and will: «St. Germ’s scraped away at us, leaving holes in our beings» (IH: 52).

The risk for Saul is to resemble the little Indian girl he sees in one of the corridors upon leaving St. Jerome's, an automaton whose eyes reflect the unfathomable void left by years of ill treatment and deprivation: 
No one was about except for one girl I did not know, wiping down the walls with a sponge. She was nine, maybe ten, but the smock sagging to her knees and her dark stockings and shapeless shoes made her look like an old woman. I coughed, and she looked for a moment. There was no recognition on her face, no expression except surrender. When I made a small wave she raised her chin an inch or so, gazed at me with dark, empty eyes and then reached down to squeeze her sponge again. (IH: 97)

If Saul avoids destruction, it is only because he quickly understands that withdrawal into books and retreat within himself can protect him from the unspeakable horrors which characterize everyday life at St. Jerome's:

I learned that I could draw the boundaries of my physical self inward, collapse the space I occupied and become a mote, a speck, an indifferent atom in its own peculiar orbit. [...] But in my chrysalis of silence I turned to Zhaunagush books and language, finding in them a path beyond the astringent smell of the school. (IH: 48-49)

What Wagamese suggests in this passage is that in that wasteland, there is still a space for creation and imagination. Reading provides an alternative space, a refuge of sorts shielding the child from the violence inflicted upon him by the dominant social group, as was the case when Wagamese found solace in writing when he was a lone, lost and bruised Indian boy in white houses (Wagamese, 2008: 57-59). As far as his young hero is concerned, the protective power of literature also operates insofar as Saul manages to escape destruction and eventually to move away from St. Jerome's.

2. CONCEALING THE UNSPEAKABLE: REPLACEMENTS AND WANDERINGS

Yet, for all the potential of literature, what really saves Saul from St. Jerome's is the introduction of ice hockey by a new young priest named Father Leboutilier. Hockey 
colonizes over one hundred and ten pages—or half the novel—as it fills Saul's otherwise vacuous life. This is particularly striking in a short passage recounting Saul's dreams of hockey feats before falling asleep in the cold dormitory (IH: 62). The deliberate repetition of the frequentative aspect of the modal auxiliary «would»-fifteen occurrences in this particular instance-clearly informs the reader that hockey has now become the main focus of attention.

As a matter of fact, the game proves to be an effective antidote to the noxious influence of the destructive environment in which Saul was placed and even displaced. The ice rink provides both a spatial and an emotional framework to Saul's shattered existence. It is a space of grace and magic (IH: 63) where Saul develops visionary powers and skills not unlike those of the storytellers and the medicine men he counts among his ancestors:

There are stories of teachers among our people who could determine where a particular moose was, a bear, the exact time the fish would make their spawning runs. My great-grandfather Shabogeesick [...] had that gift. The world spoke to him. It told him where to look. Shabogeesick's gift had been passed on to me. There's no other explanation for how I was able to see this foreign game so completely right away. (IH: 58)

On the rink, Saul regains agency by controlling his movements and the space around him. A sense of place and timeliness is thereby restored enabling him to express his creativity in an otherwise barren environment (IH: 64). Metonymically speaking, the structuring properties of ice hockey also provide a timeframe and a pace for the narrative which organises itself around the many games and training sessions that abound in the text.

Moreover, playing hockey also fuels Saul's thirst for social ascent. Indeed, the game possesses metamorphic powers insofar as it can «transform ordinary men into great ones» (IH: 57)—into heroes or legends—by promising them to achieve posterity. Hockey also constitutes a true opportunity for elevation since it allows Saul to transform his story of shame and dispossession into a tale of glory and fulfilment. Furthermore, it offers a way out - a safe-conduct out of the boarding school-by allowing the young boy to leave St Jerome's and go and live with the Kellys, an Anishinaabe family whose male members manage a local Aboriginal hockey team in Manitouwadge, Ontario.

There, hockey continues to be a refuge for Saul. Being part of a team helps him 
foster a feeling of belonging he had not experienced since his grandmother's death. This was already true when he played on St Jerome's team, but it becomes all the more obvious when he starts playing with the Manitouwadge Moose: «Brothers. Joined by the promise of steel blades forming swirls in snow and ice» (IH: 86). In this soothing and benevolent environment, he becomes one with the group as if he were a vital organ in a living organism: «an essential part of the Moose» (IH: 111).

This sense of belonging, which, according to French philosopher and historian Tzvetan Todorov is the only way for man to avoid obliteration and oblivion (Todorov, 2004: 52-53), is provisionally restored as the team replaces the small community from which Saul was alienated. For instance, the team captain, Virgil, has inherited his role from his father, Fred Kelly, as a tribal Anishinaabe chief would have in precolonial times (IH: 100). Additionally, the Moose appear to behave as a tribe which makes them impervious to the dispossessions, the pressures and the humiliations suffered at the hands of the dominant group. By establishing a cohesive force, they challenge their very status as a marginalised minority in order to reclaim the nomadic lifestyle their forefathers were denied more than a hundred years before. In doing so, they develop a sense of freedom, empowerment and confidence which helps them endure in spaces and places where their legitimacy is constantly questioned:

We were hockey gipsies, heading down another gravel road every weekend, plowing into the heart of that magnificent northern landscape. We never gave a thought to being deprived as we travelled, to being shut out of the regular league system. We never gave a thought to being Indian. Different. We only thought of the game and the brotherhood that bound us together off the ice $[\ldots]$. We were a league of nomads, mad for the game, mad for the road, mad for the ice and snow, an arctic wind on our faces and a frozen puck on the blade of our sticks. (IH: 113)

Thus, Saul seems to have found a firm ground on which to rebuild his life and reconstruct his personal narrative at last— the solid framework without which, as French neuropsychiatrist Boris Cyrulnik explains in his seminal essay on traumatic memory and resilience, no narratives or perspectives are possible (Cyrulnik, 2010: 40). At this stage, it seems that hockey as well as the fosterage provided by the Kellys enable Saul to move beyond his trauma and pursue his dreams of glory. The cathartic function of hockey is repeatedly 
highlighted as the link between the game and the need to reconquer stolen territories becomes more and more obvious (IH: 114-115). The inverted metaphor of colonisation appears in the few paragraphs recounting the games opposing the Moose to other Aboriginal teams. What the reader is provided with in these passages is a reconfiguration of the horse and warrior culture which marked the heyday of most Native tribes in the great plains and prairies of North America before forced settlement onto reservations left them paralysed:

The game brought us together in a way that nothing else could, and players and fans alike huddled against whatever winter threw at us. We celebrated every goal, every hit, every pass. [...] We came from nations of warriors, and the sudden flinging down of sticks and gloves, the wild punches and wrestling were extensions of that identity. (IH: 110-11)

This is a recurrent feature in Indian narratives where ancestral meanings are rescued from oblivion by being transferred to modern symbols and situations. Indeed, Wagamese's reconfiguration of a war party reminds us of one of Sherman Alexie's most famous shortstories in which a car ride becomes the re-enactment of a horse-stealing raid (Alexie, 1993: 53). In this respect, Wagamese is clearly in line with fellow Native authors such as Alexie or James Welch who constantly try to provide a space for traditional artefacts, ways and practices in their narratives set in modern-day Canada or America. In this particular instance, hockey serves as a social and cultural cement between the various Aboriginal groups by encouraging cross community contacts and by reviving a glorious past that the colonial power had sought to eradicate—an inter-tribal history which binds their members together.

The magic of hockey, however, ceases to work as soon as the Moose start playing local white teams. Their initial victories force them to venture into hostile and dangerous territories. Right from the first few games, the animosity displayed by the spectators and the opposite teams leaves no doubt as to the young Indians' status as second-class players or even as intruders: «The crowd was rabid. Garbage rained down on us. A group of them pissed and shat in our dressing room» (IH: 131).

Soon enough, the Moose discover that ice hockey arenas are meant for white players only, not for Indians. The elation they used to feel during the games gradually gives way to resentment at the idea of being treated as mere foils to the home teams at best, and as savages in most cases $(I H: 130-131)$. Their many victories offend their white contenders 
and their supporters who «only [see] brown faces where white ones should have been. [...] an unwelcome entity in their midst» (IH: 132).

This hatred, however, is at its highest when the Moose stop at a diner on their way back home after another win. There, they are attacked by a gang of white working men who beat them up and urinate on each of the Moose players but Saul. Obviously, the adolescents have trespassed on two spaces where Indians should never venture-the ice hockey arena and the local diner. By urinating on them, the white men assert their dominance over territories which the young Indians had wrongfully conquered. They literally downgrade them to the status which is theirs: that of subalterns (IH: 133-135)

As Choctaw-Cherokee writer and academic Louis Owens once wrote, rediscovering a sense of place as well as community is at the centre of American Indian fiction (Owens, 1992: 5). It comes as no surprise then that Wagamese should use ice hockey as a metaphor of the vital need for his alienated character to reclaim a space from which he was initially evicted. The link between the dislocation of the self subsequent to the acculturation process and the original displacement and relocation of Native communities as theorised by RigalCellard (Rigal-Cellard, 2004: 72-79) is a salient feature in Indian Horse. Saul's shattered life only holds together because hockey offers a possibility to escape his condition as a subaltern. By seizing the opportunity to move to Toronto to play in the National Hockey League, he incarnates his fellow players' dream to move out of the place where their communities have been stranded for over a century - the reservation-and conquer, or rather reclaim new spaces (IH: 153).

Nevertheless, as Saul himself stresses, «Toronto was a chimera» (IH: 158). There, in the big city, he feels utterly lost and completely uprooted. For the other players, he is no more than a number on a hockey jersey $(I H: 162)$ and, in the end, he is as much out of place in the urban landscape as the racoon he spots one night in a rubbish pile:

There were no rocks. There was nothing wild. The one time I stepped out late in the evening and surprised a racoon in the trash pile we stared at each other in amazement. Him to see an Indian in that jumble of glass and steel and concrete, me to see a creature meant for hinterlands where the wind carried animal sign instead of rot and decay. (IH: 158) 
Among the white players and supporters, Saul is constantly marginalised: an Indian boy with a funny Indian name coming from a remote place in the hinterland. Once more, his achievements on the rink only result in more hatred and violence. Ignored by his teammates (IH: 163$)$ and bullied by the players on the other teams (IH: 164), Saul epitomises the impossibility for Aboriginals to stray from the narrow path traced by 150 years of assimilation policies. A prime example of this is found in the sports section of the local newspapers where his behaviour on the rink is systematically assessed in terms of warfare and savagery, reducing him once more to his subordinate position as an Indian:

But the press would not let me be. When I hit someone, it wasn't just a body check; I was counting coup. When I made a dash down the ice and brought the crowd to their feet, I was on a raid. If I inadvertently high-sticked someone during a tussle in the corner, I was taking scalps. When I did not react, I was the stoic Indian. One reporter described how I looked flying across the opposition blue line with the puck on my stick: I was as bright-eyed as a painted warrior bearing down on a wagon train. The explosively fast, ordered game I was learning to play had set me on fire. I wanted to rise to new heights, be one of the glittering few. But they wouldn't let me be just a hockey player. I always had to be the Indian. (IH: 163-164)

Soon enough, he can no longer cope with the prevailing hostility and he starts to develop an aggressive game- to be the savage that the white crowd expects him to be. Then, not only does Saul lose the grace that characterized him on the ice (IH: 165), but he also renounces his dreams of fame and achievement (IH: 166). He has literally fallen from grace as his ascent is brutally ended by his decision to lower himself to the condition to which the whites meant to reduce him and to become «the Rampaging Redskin» described in the papers (IH: 165).

After his decision to return to Manitouwadge and drop hockey, Saul once more faces the vacuity of his existence-the hole that St. Jerome's has left in him. This void materialises in chapter 39 when the fragmented memory of a terrible episode- the murder and the suicide of two young Indian girls-resurfaces (IH: 167-168) and fills in the blank between his decision to leave Toronto (chapter 38) and his return to Manitouwadge (chapter 40). This is a sign that hockey operated as what Paul Ricoeur, quoting from Freud, calls a transfer, or a transitional state between a dysfunctional memory and real life (Ricoeur, 2000: 85). Once hockey is gone from the text and from Saul's life, the pain and the darkness 
left by the years spent at St. Jerome's resurface as the boy's rage grows out of control and the «frigid blackness inside» returns (IH: 175).

The ice rink has now ceased to be the space of future opportunities and heroism to become the place where a destructive anger expresses itself and precipitates Saul's downfall as the Moose are eventually forced to expel him too (IH: 176). Without hockey, the one substitute that allowed him to fill the gaps left and the losses caused by his traumatic past at the boarding school, Saul chooses an even more marginal position by leaving Manitouwadge in search of a place or a space that does not exist, becoming «a wandering nomad with [his] eyes on distant hills» (IH: 179).

This vagrant existence offers another antidote to Saul's solitude and deep psychic pain, another addiction that keeps him from facing the truth of his experience at St. Jerome's. Indeed, as soon as he starts drinking, the rage within himself is completely numbed in the «dim world» in which he has now withdrawn:

I'm not sure when I began to drink myself. I only know that when I did the roaring in my belly calmed. In alcohol, I found an antidote to exile. I moved out of the background to become a joker, a clown, a raconteur who spun stories about madcap travels and events. None of them had actually happened to me, but I had read enough to make these tales come to life, to be believable and engaging. Amid the slaps and pokes and guffaws that greeted them, I discovered that being someone you are not is often easier than living with the person you are. I became drunk with that. Addicted. My new escape sustained me for awhile. (IH: 180-181)

Thus, intoxication has made Saul a «raconteur» rather than a storyteller. As a matter of fact, the stories he tells his inebriated audience in the local taverns are adulterated narratives that only serve to conceal his Indianness rather than express it. In the end, when he passes out, he once more becomes just what a white audience expects him to be-another drunken Indian, «a caricature everyone sought to avoid» (IH: 181). Storytelling, which in most Native oral cultures is meant to reveal meaning, to inform and elevate both the teller and the listener (Rigal-Cellard, 2004: 23), is entirely divested of its sacred functions to serve completely opposite purposes. Saul is unable to ground his stories in tribal history and myths, in the shared memories that, as his grandmother once taught him (IH: 12), allow one to transform microscopic events into age-old stories able to resist annihilation. 
Predictably enough, Naomi's death has a profound impact on the narrative. Saul's ability to tell his story gradually dwindles as Naomi's voice fades away in the winter storm and as her stories are scattered by Kewatin, the cruel winter wind (IH: 36-40). Her passing away is reported in a rather dry and unemotional tone, a news-writing style of sorts, that not only reproduces Saul's inability to cope with her sudden loss and the alienation it entails, but also marks the beginning of a long stasis which freezes the narration of Saul's story until one spring, years later, when he decides to return to Manitouwadge and face the truth of his experience:

I tucked my head in against her chest. She held me and we lay there in the darkness shivering. I could feel her tremble. Wrapped in the cracked canvas of an old tent, I huddled in the arms of the old woman and felt the cold freeze her in place. I understood that she had left me and I lay there crying against the empty drum of her chest. (IH: 42)

Afterward, the young boy withdraws into the little space he manages to secure for himself at St. Jerome's, learning to «collapse the space [he] occupie[s] and become a mote, a speck, an indifferent atom in its own peculiar orbit», retreating in his «chrysalis of silence» (IH: 49). Since his true story has now become beyond his reach, he starts imagining alternative narratives, forged or adapted memories. This is in fact a common strategy enacted by the human brain when the real experience is too hard to believe and cope with (Cyrulnik, 2010: 16). As Cyrulnik also reminds us, traumatic memory transforms, amplifies, minimises and distorts narratives (Cyrulnik, 2010: 16). Such is the case in Indian Horse when right after his grandmother's death, Saul starts imagining a happy ending to their attempt to survive the snowstorm:

If our canoe hadn't hit that boulder we would have made it to Minaki. We would have found Minoose and sheltered there, and my grandmother would have found a way to keep me with her. Instead, she was gone. Frozen to death saving me, and I was cast adrift on a strange new river. (IH: 42)

The profusion of epistemic modals in this attempt to rewrite the story of Naomi and her grandson's desperate race against the winter wind is cut short by the terse reminder of the old lady's demise, as if the possibility to tell stories had died with her in the snow. 
From that point, the novel is cast adrift as well, as Wagamese devises a set of narrative strategies that lead the reader astray and divert our attention from the one element that could help us make sense of Saul's experience.

Silence, for instance, plays a key role in protecting Saul from annihilation. It provides a refuge where he is not only safe from external dangers, but also from the extreme violence within himself each time he suffers new humiliations (IH: 180). Silence, however, is often more eloquent than words would have been to express the atrocities witnessed at St. Jerome's. Such is the case when Father Quinney, the school's principal, punishes Shane Big Canoe as the other children hear the scene from the corridor: «We heard slaps, the whack of fists on flesh, the sound of wrestling, and the crash of furniture. Then silence» (IH: 51). In this extract, the sharp contrast between the profusion of alliterations reproducing the sounds heard by the pupils and the blanks left in the text—we are not given any graphic account of the beating-reveal how Wagamese manages to use the silences of the text to express the horrors of the residential schools better than any detailed description of the scene would have. In fact, what the novelist does here is use the dominant language imposed on him to build a soundscape that suffices to expose the atrocities committed upon the young Indian wards.

As a result, the reader's attention is drawn to the fact that the text does not always tell the whole story. To quote Paul Ricoeur, what the text leaves unsaid mirrors a form of amnesia that helps the victim cope with the violence of the experience and of the traumatic memory (Ricoeur, 2000: 576-578). Another instance of this is found when the Moose agree to keep their humiliation secret after their infamous experience at the small diner in Chapleau. Their rage and their frustration at the memory of being urinated on by dominating white men does not surface in verbal language but in the looks they exchange (IH: 136). Similarly, Wagamese offers no comment on the sexual abuses suffered by the young Indians in the dormitories. Only the empty look in their eyes meant to conceal their shame reveals the terrible ordeal they went through: «Where they went and what happened to them was never spoken of. In the daylight we would look at each other blankly, so that we would not cause any further shame» (IH: 81).

Sometimes, the difficulty to recover stolen memories appears not so much in the silences of the text, but in the allusive nature of the stories told. For instance, when Saul tries to remember the day when he first saw lake Manitou Gameeng, his family's sacred place, he 
uses unusually short sentences-noun clauses mostly-whose content oscillates rather strangely between facts and metaphors. Such oscillations as well as the syncopated rhythm of the passage epitomise the process through which Saul's dysfunctional memory seizes fragments of his story to try to recompose a fuller picture (IH: 37-38). Here, as Cyrulnik argues, traumatic memories function as a patchwork whose pieces have been mixed up (Cyrulnik, 2010: 24). These fragmentary memories regularly resurface in the narrative and both the reader and Saul are brutally overcome by the emotions triggered by the resurgence of a particular detail associated with the trauma. When Saul describes Sister Ignacia, for example, the recollection of her bulky figure suffices to bring back the panic that struck and paralysed him as a schoolboy: «She was a large woman, tall, and I'd never known such terror» (IH: 47).

Another strategy adopted by Wagamese to mirror Saul's inability to reconstruct his story consists in what could be called the «aborted narrative». This is the case when Saul fails to bring his relation of his brother's death to a conclusion (IH: 157) or when Fred and Martha Kelly leave their narration of their own experience in the residential school system unfinished (IH: 157).

These stories are left unresolved then while others, which do find a conclusion, only serve to conceal another story that language cannot express. Chapter 13 offers a prime example of what could be called a concealed narrative. It is inserted between the relation of two highly traumatic memories-Shane Big Canoe's martyrdom and the enumeration of the horrors Saul witnessed during his years at St. Jerome's. In this extremely short chapter, we are told about a fishing party in the small brook that flows near the school. This experience is one of the very few moments of freedom and entertainment in the drab lives of the young Indians, a source of great joy and merriment at first, which soon ends up in tears and bitterness. The image of the fish they caught gasping for air on the riverbank compels the children to put them back into the water. Unexpectedly, they burst into tears as they watch the fish swim away. This apparently trivial episode conveys in fact more meaning than any fully-fledged description of the children's confinement at St. Jerome's. In a single sentence, the reader understands the extent of their distress when they realize that they are the fish struggling for air on a riverbank, but that unlike the real fish they have just released, they have no means to escape the tragedy to which they are doomed: «When they lay gasping on the grass, it was ourselves we saw fighting for air. We were Indian kids and all we had was 
the smell of those fish on our hands» (IH: 54) ${ }^{9}$.

As a matter of fact, when Saul decides to leave Manitouwadge and lead a wandering life, he is still one of those fish stuck on the riverbank. Intoxication keeps him paralysed and he cannot make sense of a story he is still unable to re-member. As Todorov would contend, his literal interpretation of the successive traumas he suffered makes his memories intransitive, preventing him from moving forward and from overcoming his pain (Todorov, 2004: 30-31). Drinking becomes a metaphor of forgetfulness, an alcohol-induced state of amnesia, «the world at the bottom of the well where you huddle in darkness, haunted forever by the knowledge of light» (IH: 189). As Ricoeur reminds us by quoting Freud, acting out and developing compulsive behaviours-drinking in this particular instance-acts as a substitute for remembering. In other words, Saul dissolves himself into noxious mixtures to avoid resolving his trauma.

The «knowledge of light» is still there, however, and ultimately leads him to a place with an auspicious name, The New Dawn Centre, where he enrols in a rehabilitation programme and starts writing about his experience as his recollections become clearer, able at last to «surface into the light for the first time in a very long time» (IH: 190).

Remembering is a slow process though and involves a retrospective approach, a regressus ad initium of sorts, which leads the victim of a traumatic experience back to the time and place where the original event occurred. A number of neuropsychiatrists such as Cyrulnik have shown how returning to the place of the initial trauma triggers emotions which bring back to the surface the repressed memories that in turn facilitate recovery by releasing other emotions hidden behind the veil of false or substitute recollections (Cyrulnik, 2010: 51). Thus, as soon as Saul manages to reconnect with his past through a vision in which his ancestors visit him, he realizes that the place he had been heading to all this time was nowhere else than St. Jerome's (IH: 192). Once he is back on the site of the ruins of the former residential school, he witnesses the signs on the crumbling walls of the anger and the violence unleashed by former students who also returned to the place of their suffering (IH: 195-196). He is suddenly overcome, however, by his own rage and distress when the sight of the collapsing hockey rink causes him to start sobbing uncontrollably. Releasing the

\footnotetext{
9 The parallel between the fish gasping for air and the helplessness of the young Indians is evocative of the passages in Momaday's House Made of Dawn where Abel's condition in Los Angeles is equated to that of a school of fish stranded on the shore (Momaday, 1968: 79).
} 
pressure that had built up year after year since the death of Naomi opens up a space within himself allowing the repressed memory to resurface as suddenly as it had vanished: Father Leboutilier, who introduced him to ice hockey and was repeatedly presented as Saul's saviour, took advantage of the young boy's passion for the game to rape him repeatedly before and after their training sessions (IH: 198-199).

As Saul is overwhelmed by the flow of emotions triggered by the recollection of the abuses he suffered, the reader is compelled to experience the sudden shock caused by the resurgence of the repressed memory of the rape. Indeed, nowhere in the novel did Wagamese allow his reader to guess Saul's long-buried secret. Only then do we understand that the colonisation of the text by ice hockey was nothing more than a metaphor of Saul's need to hide the unbearable truth, to fill the void left by the desecration of his body and mind with a substitute structure: «I used the game to shelter me from seeing the truth, from having to face it every day. Later, after I was gone, the game kept me from remembering. As long as I could escape into it, I could fly away. Fly away and never have to land on the scorched earth of my boyhood» (IH: 199).

In the end, the uncanny precision with which Wagamese reported the various hockey games reminds the reader of a process identified by many experts on traumatic memory as hypermnesia, or the exaggerated precision or proliferation of recollections. This dysfunctional process signals the victim's need to forget and to replace the impossible memory with gap filling memories that give consistency to an otherwise disjointed narrative (Cyrulnik 2010: 38; Freud 1984: 101).

As Saul manages to reclaim the missing element that enables him to reconstruct his personal narrative, he is able to trace the story back to the one place where things will eventually make sense-lake Maniton Gameeng. While he is sailing up the river-yet another metaphor of memory and remembering - he recalls the founding myth of his family, which, somewhat ironically, begins with a downfall since it involves the death of ancient relatives after the collapse of a cliff (IH:23-24). The lake is therefore «the place where everything started and everything ended» as Saul reminds us (IH: 206). By getting closer to both the beginning and the end of the story, Saul not only understands that the memory of this sacred place never left him, but he also manages to fully assess the significance of his heritage and make sense of his history both as an individual and as a member of the Indian Horse clan (IH: 205-206). 
3. RECLAIMING FORMS AND STRUCTURES: A SPACE OF ONE'S OWN

Logically, the two chapters recounting the journey to the lake open with the same sentence (IH: 21; 204). Although the «we» pronoun of chapter 6 has been replaced by the «I» in chapter 51, where Saul embarks on the same journey but on his own this time, the reader senses that the circle is almost complete. Indeed, the whole narrative can be read as a loop that reminds one of the seasonal cycle, which is hardly surprising considering the prevalence of circular time in Native literatures (Rigal-Cellard 2004: 88). Thus, winter announces the initial loss (Naomi's death), whereas spring, whose coming Saul dreaded when his survival depended on hockey games (IH: 93), is precisely the season he chooses to return to Manitouwadge at the end of the novel. At that stage, the narrative starts to flow again after years of stasis (IH: 207).

Lake Manitou Gameeng constitutes what Vine Deloria calls the sacred centre, the place where the relation of and to tribal history becomes possible again (Deloria 1973: 66). The idea that in many Native cultures history and geography are interconnected through what is referred to as spatial time (Deloria 1973: 102; 121) is central to Wagamese's novel. On the lake shore, Saul lets all the rage and hatred go and ceases to be the hostage of his «captor, the warder of [his] innocence»: Father Leboutilier (IH: 202). Once he has cleansed his mind and body, he makes offerings to the spirits of his ancestors and to the lake before praying aloud in Ojibway (IH: 205-206). The use of his mother tongue for the first time since his grandmother died marks the end of Saul's alienation as well as his decision to reconnect with the tribal memory of his people.

This brings us back to the opening chapter of the novel whose chronology is, as mentioned earlier, resolutely circular. After reconnecting with the sacred centre where history dwells, Saul returns to another centre, The New Dawn Centre in Winnipeg, where his rehabilitation treatment involves sharing his story with the other patients. At first, he is unable to share his narrative orally during the talk therapy sessions. So, he undertakes to write it down rather than speak it (IH: 2-3). The situation Saul faces metonymically recalls the predicament in which Aboriginal communities at large found themselves when they were 
deprived of their traditional narratives partly as the result of aggressive Indian education policies

Symbolically, though, Saul's decision to use writing does not estrange him for the oral tradition from which his story originates. As Rigal-Cellard rightly argues, writing as part of the healing process is a recurrent feature of Indian literatures. As a matter of fact, setting pen to paper amounts to seizing the very weapon with which the colonising culture attempted to erase the traditional narratives. By doing so, Native writers attempt to rewrite the tribalography by incorporating elements from the Native oratures to the forms imposed by the dominant culture (Rigal-Cellard 2004: 261). Consequently, oralising the written narrative allows the survivance of the oral tradition through a medium-writing-that is both the opposite and the counterpart of the spoken story (Rigal-Cellard 2004: 29). RigalCellard's analysis perfectly applies to Indian Horse where traditional storytelling strategies and western narrative devices constantly intertwine.

The deterritorialisation of written language, a process through which writing gradually loses its original values to oral language, definitely qualifies Wagamese's novel as part of minor literatures as theorised by Deleuze (Deleuze 1975: 11-12). Logically then, the traditional narratives which had been fixed on paper-alienated as Deleuze would contend (Deleuze 1972: 162)—resume their nomadic existence as Saul relates his experience. Right from the start, Wagamese had made it plain to the reader that the novel was a markedly hybrid one in which writing was only an extension of the oral tradition as Rigal-Cellard would contend (Rigal-Cellard 2004: 13). This is hardly surprising given the fact that apart from being a novelist and a journalist, Wagamese was at the head of a group of storytellers called Deb-bah-juh-mig. This, he recalls, was a way to reconnect with the Anishinaabe culture from which he had been completely estranged for almost thirty years (Schorcht 2008: 76-77). Similarly, Saul introduces his narrative as any Ojibway storyteller would, by giving his name, his lineage, his clan and his connection with his tribe's sacred place, and of course by celebrating the power of sharing stories (IH: 1-2).

In the nine short chapters that follow, when Saul remembers the few months that preceded Naomi's death, the feeling of an oralised narrative is even stronger. Indeed, in some passages, the rhythm resulting from the succession of short sentences suggests a spoken story more than a written novel: «She sang while we paddled. Her songs sounded like prayers. I hoped they were. The cold was intense» (IH: 38). The absence of logical connectors to link 
Saul's recollections of his journey through the blizzard not only evokes an oral tale, but may also suggest what Rigal-Cellard has identified as one of the «narrative techniques of alienation» common in Indian literatures - mainly the use of a deliberately disjunctive syntax meant to reproduce a character's inability to deliver a linear and continuous narrative (RigalCellard 2004: 88). In this other passage, however, a similar feeling is produced by the use of the reverse strategy, polysyndeton-the proliferation of the coordinating conjunction «and»—to associate apparently dissimilar elements:

We ate without speaking and my grandmother kept her eyes on the river. The water was black with the cold. We edged the canoe closer to the fire and tilted it and she put spruce boughs on the ground and over the hull to form a lean-to, and that's where we slept that first night. We could hear wolves and the snapping of branches in the trees and she pulled me closer. (IH: 37)

As the plot unfolds, the spoken story emerges in a way that is characteristic of the traditional approach to storytelling among the Ojibway. At the end of the novel, when Saul tries to tell Virgil about the rape and cannot find a way to start his narration, the latter initiates the narrative in his stead and the tale is reconstructed jointly by the two Indian boys (IH: 216217). The role of the listener in the construction of meaning-which Cree poet and academic Neal McLeod identified as one of the specific features of Algonquian storytelling traditions (McLeod 2014: 96)—is therefore reasserted by Wagamese while the healing power of the shared narrative ultimately rescues Saul from the pit in which he had fallen.

These instances of the fertilisation of the novel with elements from the oral tradition coexist with passages that refer to the canonical forms and standards imported from western literature. Such is the case, for instance, when Benjamin's corpse is carried away by Saul's parents on a canoe. The image of the shimmer of the wake left by the small boat as it fades away in the distance is reminiscent of Arthurian legends $(I H: 33)^{10}$. Similarly, the image of a young Indian girl, Rebecca Wolf, stabbing herself to death on her sister's grave evokes a scene from a classic tragedy $(I H: 168)^{11}$. In fact, what Wagamese reminds us by juxtaposing these narrative devices and references is that Indian literatures are entirely dependent on the

\footnotetext{
${ }^{10}$ See Book VIII of Le morte d'Arthur by Thomas Mallaury for instance.

11 One may think, for instance, of Juliet's death in Romeo and Juliet or of the death of Deirdre in John Millington Synge's Deirdre of the Sorrows.
} 
coexistence of the western canon and the Aboriginal forms, another characteristic on which Rigal-Cellard insists in her assessment of North American Native literatures (Rigal-Cellard 2004: 13).

Beyond the obvious references to some classics of western literature, what makes the interaction between traditional and imported or even imposed forms even more forceful is most certainly Wagamese's propensity to redefine the structure of the novel. The text is a shapeshifter of sorts, and the author acts as a trickster, an element of traditional Indian narratives which, as Rigal-Cellard stresses, at once disrupts and restores the order of the story (Rigal-Cellard 2004: 321-348). Indeed, Wagamese constantly disseminates misleading elements through the novel, which enables him to retain control of whatever level of understanding is accessible to the reader. For instance, as has already been noted in this study, it is impossible for the reader to anticipate the resurfacing of the repressed memory of Saul's rape. Father Leboutilier is alternately referred to as Saul's ally (IH: 63), friend (IH: 57), protector (IH: 68) and even saviour (IH: 98). Before vanishing from the narrative until the resurgence of the traumatic memory of the sexual abuses he forced Saul to endure, he is portrayed as a substitute to Saul's grandmother as he offers the boy the affection and love he was craving (IH: 59). Although his physical intimacy with Saul may seem strange, especially within the context of a story on Indian residential schools in Canada, Wagamese systematically uses Saul's amnesia to compel the reader to have a positive understanding of the young priest's behaviour and gestures, thus blocking access to the true motives of Leboutilier's attentions:

Father Leboutilier loved the game more than anybody. When he coached us or watched the televised games, he lost the solemn priestly façade and became a boy again., licking his lips in anticipation. His relish was infectious.

So it didn't surprise me when he began to show up at my early morning solo practices. (IH: 83)

It is only when the reader understands that the morning practices and the moments when Saul and the oblate watched the games in the priest's bedroom where the very moments when the assaults took place that the nature of Leboutilier's fascination for the boy is revealed. The capacity of the narrative to conceal as much meaning as it seems to reveal is, in this respect, a clear extension of the role usually played by the trickster in traditional 
tales as both a deceiver and a helper (McLeod 2000: 39; 52-54).

Nevertheless, Wagamese's ability to manipulate the written narration goes even further. In Indian Horse, the very structure of the classic novel is altered and redefined. This is yet another major characteristic of minor literatures as defined by Deleuze: their ability to introduce new structures or alter the existing ones in an attempt to reterritorialise the narrative (Deleuze 1975: 12). Although the novel is divided into chapters, most of them are very short. Some are closer to narrative vignettes of sorts through which Wagamese uses the interstices between two chapters to insert micronarratives meant to reproduce the resurfacing of traumatic images in Saul's memory. What appears in these interstices created by Wagamese is the extent of the violence exerted on the children. In Chapter 12, for instance, three unbearable memories - the faces of three Indian children dying from the illtreatment suffered at St. Jerome's-brutally disrupt the apparent linearity of the narration, thereby reminding us of the extent of the atrocities perpetrated in some residential schools (IH: 49-52).

For Wagamese, the story itself suffices and there is no need for long diatribes against the horrors that took place in over one hundred years of abduction and forced education of Indian children in Canada. In these particular instances, the text, as he once stressed in a conference, is not concerned with poetry (Wagamese 2013). Thus, in a passage about the prohibition of Native languages in residential schools, the shocking death of Curtis White Fox, choking on a piece of soap the nuns stuck into his mouth after he dared to speak in Ojibway, is inserted between two lines and requires no further comments to convey the full horror of the treatments inflicted on the young pupils: «There was no tolerance for Indian talk. On the second day I was there, a boy named Curtis White Fox had his mouth washed out with lye soap for speaking Ojibway. He choked on it and died right there in the classroom. He was ten. So the kids whispered to each other» (IH: 48). The best illustration of Wagamese's ability to redefine the structure of the western narrative, however, is found in chapter 14. This «vignette chapter» of about twenty lines, and written in a very terse style, encapsulates all the abuses and tortures that took place in the residential school system more efficiently than any long speech would. Epidemics, malnutrition, hypothermia and waves of suicides are inserted between two longer chapters as a reminder of the extreme violence exerted on successive generations of Indian children ( $I H: 55)$.

Sometimes, the extent of this violence is magnified by the sharp contrast resulting 
from the juxtaposition of tragic and comic elements. The famous Cree author Tomson Highway, who uses similar techniques in his acclaimed novel on residential schools Kiss of the Fur Queen, explains that this is yet another specific feature of Algonquian narratives (Ghomeshi 2014). In Indian Horse, one of the passages that best epitomises this strategy is the account of Lenny Mink's brutal death just after Saul remembers a joke the young boy made on the excessive use of spanking by the priests:

«I seen more little brown nuts than a squirrel», Lenny Mink said to me once. «And more cracks than the river at spring breakup.» He was funny, that Lenny Mink. He died when they were trying to clear a stump from the end of a field and a tractor chain snapped. Lenny's head was split wide open in front of all those boys. There wasn't a funeral. There never was for kids who died. His body just disappeared and none of the priests or nuns said anything about him again. (IH: 79-80)

Wagamese manages once more to express the squalid experience of residential schools in just a few lines. The contrast between Lenny's joke and his tragic death, as well as the news-writing style that serves to relate the dreadful events leading to his demise serve to heighten the emotions triggered by the recollection. As Jack Robinson contends in one of the very few academic papers published on Indian Horse, it would be wrong to assume that Wagamese's simple and pared-down style accounts for narrative transparency (Robinson 2013: 89). In fact, it serves the opposite purpose by misleading the reader into thinking that Saul's account is just another linear residential school story.

In one of the final chapters, however, comedy and tragedy once more coexist although the effect on the reader is not the same then. Saul's pun on the word «Jesus» is one of the only moments of comic relief in the novel: "'You're one of those kids, aren't you? One of the ones the schools fucked up. [...] Jesus'. - 'Don't think he had anything to do with it, really.' He turned in his seat. «I know. I'm sorry. Crap choice of words” » (IH: 216). Resuming command of language, the very language imposed on them by the schools, is thus the only means to take the necessary distance to make sense of the story and regain agency.

Words, or rather the natural energy of language as Rigal-Cellard explains (RigalCellard 2004: 28), are often endowed with specific powers in Indian narratives. This is something Saul had been made aware of at a very early stage in his life when his grandmother had warned him against the dark powers of the English language, a spell used to lure Indian children away from their native communities and better acculturate them: «They come in 
different ways, them, the Zhaunagush ${ }^{12}$. Their talk and their stories can sneak you away as quick as their boats» (IH: 10). Indeed, within the narrow limits of St. Jerome's, Native languages are proscribed. For fear of the terrible punishment awaiting those who dare to speak their mother tongue, the young Indians learn «to speak without moving their lips» developing «an odd ventriloquism that allowed them to keep their talk alive» without risking death by choking as befalls poor Curtis White Fox when he breaks the rule (IH: 48).

The children keep articulating their Aboriginal languages without uttering a single sound. They are literally reduced to silence and become the dumb witnesses to the horror scenes that are part of everyday life at St. Jerome's. As a result, none of them dares speak a word to comfort young Rebecca Wolf, who has just been released from the iron sister- the tiny cage in which defiant pupils are locked-, when she is told about the death of her younger sister and starts tearing her hair and face in the school's entrance lobby. Only when she takes her own life by stabbing herself in the stomach over her sister's grave do the other kids defy the prohibition on using Indian tongues and start singing a sacred song in Ojibway. The proscribed language has thus managed to survive beneath the veil of submission.

Nevertheless, in a system where education relies on the parrot-like repetition of fixed sentences (IH: 49), access to the dominant language is also restricted. The pupils are required to learn it, but they are prevented from using it as a tool to challenge the destructive process at work in the residential schools. Saul is the only exception insofar as he already understands and speaks enough English to be able to read. Although his language skills isolate him from the other Indian children who call him «Zhaunagush» (IH: 48), they save him from alienation and annihilation by providing a refuge and an opportunity to improve his command of English through reading while the others are deliberately kept in a form of linguistic dependence: «Since I could already read and speak English when Father Leboutilier came along, I was given access to books from the town library. But the others had to read from primers and never gained facility with the language» (IH: 79).

Just like Tomson Highway in Kiss of the Fur Queen, Richard Wagamese offers an approach to residential school issues that deliberately differs from the political correctness observed in Canada since the TRC ${ }^{13}$ started investigating on Indian education. Although he offers a reflection on the cultural genocide orchestrated by the state and the churches, as well

${ }^{12}$ Zhaunagush means «white man» in Ojibway language.

13 The Truth and Reconciliation Commission of Canada (2008-2015). 
as the atrocities perpetrated in the schools, he also assesses the benefits of exposition to the dominant culture through the residential schools. After all, the prescribed languageEnglish-is, as Wagamese stresses in an interview, the very source from which the novel draws its strength (Schorcht 2008: 77). This ambivalent relationship with English is reminiscent of a phenomenon that fellow Anishinaabe writer and academic Gerald Vizenor associates with the notion of survivance of the Aboriginal cultures-the fact that English is at once «the linear tongue of colonial discoveries, racial cruelties, invented names, simulated tribal cultures, and the unheard literature of dominance in tribal communities» and «a language of liberation for many tribal people» (Vizenor 1993: 27).

It is hardly surprising then that Saul should reinvest the words imposed on him at the catholic school to relate his story. Words such a «beatific», to refer to sister Ignacia's face after she beat up Lonnie Rabbit (IH: 47), or «regimented», to evoke the children's movements in the corridors (IH: 44), are clearly identified by Saul as gifts inherited from his years at St. Jerome's. What is happening here, however, is that Wagamese subverts the vocabulary learnt in the Canadian school system to offer a critical comment on the Indian policies implemented by the Canadian government.

Beyond the meaning of words though, Wagamese also excels in using the sounds of English to put into perspective historical and social elements he means to insist on. For instance, here is the description Saul gives of Manitouwadge when he first sees the small town where he is sent to live: «The town proper was populated by tough narrow-minded men and their loyal women and their callow kids, all rough-and-rumble and rude» (IH: 99). In this sentence, the alliterations of harsh consonants—/t, p, d, k, r/—perfectly conveys the hostility and the underlying violence between the town dwellers and the small Indian community living at the edge of the town on the reservation. Ultimately, the sounds of the tribal stories which, as Vizenor deeply regrets, were lost in the visual images imposed by the dominant narratives (Vizenor, 1993: 9) reverberate again through a skilful manipulation of English phonetics.

English, however, is not the only language reclaimed by Wagamese. As a matter of fact, Ojibway words survive in the text and further add to the hybridity of the novel. Place names in Ojibway, for example, participate in the peculiar musical quality of Indian Horse while reminding the reader of the initial despoliation of Indian land. The «invented names», as Vizenor calls them (Vizenor, 1993: 27), haunt the narrative. This is the case of «Gods 
Lake» (IH: 20), the desecration of Saul's family's sacred place by early missionaries, which survives in the novel in its original version-Manitou Gameeng ${ }^{14}$.

The parallel between the eradication of Native tongues and cultures and the eviction of the First Nations from their territories is particularly striking in the passage where Saul, who has just been recruited to work as a logger, takes refuge in the surrounding forest: «The land was a presence. It had eyes, and I was being scrutinized. But I never felt out of place. [...] I wondered if this was what it meant to be Indian, Ojibway. A ritual. A ceremony, ancient and simple and personal» (IH: 172-173). Similarly, he often draws parallels between his personal story and the history of Aboriginal communities in Canada. Thus, his childhood is referred to as a «scorched land» from which he has been evicted (IH: 1999), while the rape he endured is described as an intrusion, an invasion of sorts which evokes the colonisation of the American continent: «When they invade your spirit, it's rape too,' Fred said. - I nodded. 'That's how I felt. Invaded.' » (IH: 210).

As Wagamese once argued, Indian Horse is a novel about reclaiming history (Wagamese 2013). The first step consists in reclaiming collective history by writing a counternarrative of colonisation or by inserting history in the interstices of fiction and vice versa. Studies in the field of neurosciences such as those carried out by Gerald Maurice Edelman tend to show that human memory does not focus so much on historical facts as on the emotions they trigger (Van der Kolk 1991: 439). As a matter of fact, Wagamese is more concerned with the impact of the images he uses than with giving a detailed account of the reality of life in a residential school. The existence of a torture device used against uncooperative children and called the «iron sister» (IH: 48; 167), for instance, has never been confirmed. Historicity, however, does not matter in this particular instance. What does matter is the violence of the treatment inflicted on the young Indians, of which the «iron sister» is only an illustration.

The opposite process can also be found in some passages where History and fiction intertwine. For instance, the conversation between Father Leboutilier, Father Quinney and Sister Ignacia about the possibility of letting Saul leave St. Jerome's and start a career as a hockey player provides a clear insight into the hypocrisy behind Indian education. Sister Ignacia's deceitfully protective behaviour when she suggests saving Saul from «the influence of a soulless game» is matched by Father Quinney's attempt to convince himself and his

${ }_{14}$ The closest translation would be «lake of the spirits», or «mystery lake». 
audience that his is a noble and charitable mission: «To hold him back from nurturing a gift that is divine in nature would be counterproductive to what we set out to achieve» (IH: 9697).

Such «micro counternarratives» are a form of resistance too since they challenge the widely accepted and sanitised version of the history of Indian education in Canada that still prevails despite the damning evidence of mistreatment and abuse brought by the TRC in their final report (TRC 2015). Telling history from the margin ${ }^{15}$, as Wagamese does, telling it as an author from a minority culture in the majority language, amounts to reclaiming a memory - the beliefs of a whole people - that «history trampled under foot» as Saul aptly remarks (IH: 5). As Wagamese argues, the history of Canada cannot be understood separately from the history of relationships with the First Nations. Consequently, the dissolution, the loss and the reintegration of tribal stories and customs in the narration are necessarily part of a more general historiography (Wagamese 2013).

Logically then, when Saul accepts the initial loss and reclaims the tribal narrative, he realizes that reconnecting with the traditional customs and stories does not signal a return to the ancient practices and ways, but rather represents an opportunity to use tribal history as a material on which to develop modern means of expression that may serve his community. This is precisely what McLeod calls «coming home through stories» after being subjected to the «ideological diaspora», that is to say, re-integrating your place as an Aboriginal writer after being estranged from your own culture (McLeod 2001: 17-19). In other words, by piecing together his fragmented self, Saul avoids the cultural schizophrenia inherent in acculturation. A new man has emerged, a man who is the weaver of his own tale (IH: 217) and who is aware of his responsibility as an agent rather than his immobility as a passive victim. As Fred Kelly rightly argues, «We're not responsible for what happened to us [...] But our healing - That's up to us» (IH: 210).

Telling the story then, and taking responsibility for what is told, requires that the recovered memories be used to imagine future prospects. The necessity, as Todorov says, not to let the past rule the present, but to let the present decide what to do with the past (Todorov 2004: 24) is precisely what Saul insists on when he tells Fred and Martha: «I want something new built on something old» (IH: 210). Summoning the past to build the future,

15 Deleuze goes further when he talks about writers who are marginals within an already weakened minority as Saul and Richard Wagamese are. He contends that such writers are more likely to provide fresh alternatives to the forms and models imposed by the mainstream culture (Deleuze 1975: 31-32). 
as Ricoeur once argued (Ricoeur 2000: 649), or, as Cyrulnik explains in his theory of resilience, rearranging and reinvesting the past through art (Cyrulnik 2010: 59), allows one to turn the traumatic memory and the pain it induces into a creative process (Cyrulnik 2010: 7879). This is made possible, as Martha Kelly tells Saul, by finding forgiveness without which there is no peace of mind and thus no reconstruction (IH: 209-210). This is what Ricoeur refers to as the «happy memory», or «the appeased memory» (Ricoeur 2000: 645-646)— the ability to keep the past at a certain distance in order to shape the future.

Paradoxically, by reminding us of the necessity to come to terms with the trauma left by the attempts to acculturate Indian communities in Canada, Wagamese refuses to consider residential schools as something relegated to the past. This is a point he had already made very clear in interviews given long before the novel was released, when he warned against the dangers of narratives celebrating a glorious but long-gone past as an ideal to be recovered (Schorcht 2008: 90). In a conference given at UBC in 2013, the novelist insisted on the power of fiction in the emergence of truth (Wagamese 2013). This proves true insofar as Indian Horse acts both as a cathartic and as a catalyst, helping expel the rage and the pain within, while bringing elements of truth to the surface in order to make the future possible.

Moving beyond the mere factual reality of residential schools is therefore an essential element in the reconstruction process. The purpose is not to offer a universal historical truth about the system but to understand and face one's own truth about the experience without ignoring the emotions and the recollections as painful as they might be (IH: 209; Wagamese 2013). In Saul's case, hockey was the veil that masked the truth of his experience. At the end of the novel, however, he manages to reclaim hockey as a positive element both at individual and community levels. As he tries to recover what was pure in the game, he understands that he wants to coach rather than play (IH: 218). Indian traditional narratives are mostly concerned with transmission, and this is exactly what Wagamese does in his novel, and what Saul decides to do in the end. After all, as he aptly concludes: «you reclaim things the most when you give them away» (IH: 218).

Indian Horse is thus both the story of reconstruction at a personal level and of a cultural quest whose purpose is to revive social, linguistic and spiritual systems obliterated after over four centuries of colonisation and one hundred years of forced schooling for 
Aboriginal children ${ }^{16}$. Rather than simply denouncing the abuses committed by those in charge of Indian education, Wagamese proposes a story about conciliation and the recovery of stolen memories as well as forms of expression which had been silenced for a very long time; a story in which, as Deleuze argues in his essay on minor literatures, individual and collective matters intertwine, in which the microscopic and the macroscopic cannot be understood separately (Deleuze 1975: 30-31). More than the compulsion to commemorate the past or the necessity to forget it, Wagamese praises the need to remember. To paraphrase one of Todorov's key arguments in his essay on history and memory, he avoids the morbid and excessive celebration of historical memory which hampers development and prevents reconstruction both at a personal and at a collective level (Todorov 2004: 24-25). At the end of the novel, the writing of tribal history is indeed a collective process since it amounts to the sum of the individual narratives. Access to the stories recounted by the other members of the group means that the chapter of residential schools in the history of Canada has not been closed and that a page that had never been filled before remains to be written- the story of the relationship between Canadian mainstream culture and its Aboriginal cultures (Wagamese 2013). By reinvesting and revisiting the forms imposed by the hegemonic culture, Wagamese goes beyond what he identifies as the same old story of Native victimhood (Wagamese 2012(b): 164-165). As Vizenor stated in a seminal book published in 1999, this is all about survivance and not survival. Survivance, according to him, requires ensuring the continuity and the continuance of stories and renouncing both domination and tragedywhich he calls «victimry» (Vizenor 1999: vii). This is precisely what Wagamese suggests. As he once made it plain, his purpose in writing Indian Horse was to recount a human experience - the story of a human being in search of his humanity, not of a victimised Indian looking for compassion (Wagamese 2013). There is no doubt that he has reached his purpose. By recounting and interpreting the traumatic experience of acculturation in its exemplariness, not literally, as Todorov would say, he manages to produce new media for minorities to interpret and pass on their histories (Todorov 2004: 30-31). Rather than survivors of the massacre, Saul and Richard are weavers and transmitters of stories who not only give the present generations hope for reconstruction, but also open perspectives for the

${ }^{16}$ Julie McGonegal makes a similar comment in her article on an essay on residential schools published by Wagamese in a book called Speaking My Truth (McGonegal, 2014). 
upcoming ones ${ }^{17}$ —after centuries of dissonance the possibility of a certain degree of harmony.

${ }^{17}$ Rigal-Cellard reaches a similar conclusion when she states that right from the start, Indian literature played a key role in preserving the past, the myths and history, but maybe more importantly in preparing the future (Rigal-Cellard, 2004: 372). 
BIBLIOGRAFÍA

Alexie, Sherman (1993): «This is What It Means to Say Phoenix, Arizona », in The Lone Ranger and Tonto Fistfight in Heaven, New York, Grove Press.

Cyrulnik, Boris (2010): Je me souviens..., Paris, Odile Jacob.

Deleuze, Gilles (1972): L'Anti-CEdipe, Paris, Les éditions de minuit.

Deleuze, Gilles (1975): Kafka: pour une littérature mineure, Paris, Les éditions de minuit.

Deloria, Vine (1973): God is Red: A Native View of Religion, Golden, Fulcrum Publishing, 2003.

Freud, Sigmund (1984): «Sur le mécanisme psychique de l'oubli», in Résultats, idées, problèmes,

I, Paris: PUF: 99-107.

Ghomeshi, Jian, Tomson Highway on Music and Storytelling, 04/08/2014, CBC Radio One, https://www.youtube.com/watch?v=MT7I_Sg9s3Q/ (last accessed 31/05/2019).

Highway, Tomson (1998): Kiss of the Fur Queen, Toronto, Doubleday.

McGonegal, Julie (2014): "Writing Reconciliation. », in UC Observer, November 2014, https://www.ucobserver.org/arts/2014/11/writing/ (last accessed 31/05/2019).

McLeod, Neal (2000): «Cree Narrative Memory», in Oral History Forum, 19-20: 37-61.

McLeod, Neal (2001): «Coming Home Through Stories», in Armand Garnet Ruffo (ed.) (2001): (Ad)dressing our Words, Penticton B.C., Theytus: 17-36.

McLeod, Neal (2014): «Cree Poetic Discourse», in Neal McLeod (ed.) (2014): Indigenous Poetics in Canada, Waterloo, Wilfrid Laurier University Press: 89-103.

Momaday, N. Scott (1968): House Made of Dawn, New York, Harper \& Row.

Momaday, N. Scott (2007): «The Indolent Boys», in Three Plays: The Indolent Boys, Children of the Sun and The Moon in Two Windows, Norman, U. of Oklahoma Press.

Owens, Louis (1992): Other Destinies: Understanding the American Indian Novel, Norman, University of Oklahoma Press.

Ricoeur, Paul (2000): La Mémoire, L'Histoire, L'Oubli, Paris, Seuil.

Rigal-Cellard, Bernadette (2004): Le mythe et la plume, Monaco, Éditions du Rocher.

Robinson, Jack (2013): «Re-Storying the Colonial Landscape: Richard Wagamese's Indian Horse», in Studies in Canadian Literature, 38(2): 88-105.

Schorcht, Blanca (2008): «Story Words: An Interview with Richard Wagamese », in Studies in American Indian Literatures, 20(3): 74-91.

Todorov, Tzvetan (2004): Les Abus de la mémoire, Paris, Arléa. 
TRC (2015): «TRC Final Report», on Truth and Reconciliation Commission of Canada: http://nctr.ca/reports.php (last accessed: 31/05/2019).

Van der Kolk, B. A.; Onno Van der Hart (1991): «The Intrusive Past: The Flexibility of Memory and the Engraving of Trauma», in American Imago, 48(4): 425-454.

Vizenor, Gerald (1993): "The Ruins of Representation: Shadow Survivance and the Literature of Dominance », in American Indian Quarterly, 17(1): 7-30.

Vizenor, Gerald (1999): Manifest Manners: Narratives of Survivance, Lincoln, U. of Nebraska Press.

Wagamese, Richard (2008): One Native Life, Vancouver, Douglas \& McIntyre.

Wagamese, Richard (2012a): Indian Horse, Vancouver, Douglas \& McIntyre.

Wagamese, Richard (2012b): « Returning to Harmony », in Mike DeGagné \& al. (eds.) (2012): Speaking my Truth: Reflections on Reconciliation and Residential Schools, Ottawa, Aboriginal Healing Foundation: 157-165.

Wagamese, Richard (2013): UBC Conference: https://www.youtube.com/watch?v $=$ S6HmlK27dtA (last accessed 31/05/2019).

Welch, James (1979): The Death of Jim Loney, New York, Harper \& Row. 
SOBRE EL AUTOR

\section{Franck Miroux}

Franck Miroux es profesor de inglés en la Universidad de Pau \& des Pays de l'Adour (Francia), donde imparte clases de traducción, terminología y cultura norteamericana. Es autor de diversos artículos sobre la poesía irlandesa, la traducción literaria y las literaturas indígenas de Canadá. Asimismo, es traductor jurado en el Tribunal de Apelación de Pau. La defensa de su tesis doctoral sobre la reescritura de la historia de las escuelas residenciales en las obras de ficción de autores indígenas canadienses, bajo la dirección de la Prof. ${ }^{a}$ Dr. ${ }^{a}$ D. ${ }^{a}$ Héliane Ventura está prevista en la universidad de Toulouse Jean Jaurès para el año 2020.

Contact information: Université de Pau \& des Pays de l'Adour, Collège SSH, Avenue du Doyen Poplawski, 64000 Pau, France. E-mail: franck.miroux@univ-pau.fr 